\title{
Price or Pride? Malaysian Marine Cruising Behaviour
}

Ka Leong, Chong

School of Hospitality, Sunway University, Subang Jaya, Malaysia

danielc@sunway.edu.my 


\title{
Price or Pride? Malaysian Marine Cruising Behaviour
}

\begin{abstract}
Despite substantial investments and promotional efforts in developing cruise tourism in Asia, cruise liner managers and marketers are given little indication concerning the effectiveness of their current marketing programs in driving consumer intentional behaviour. This study of a cruise liners' marketing program validates the position of emotional value, social value and perceived novelty on the consumers' intention to cruise. While marketing programs for cruise vacation in their current form do offer some brand building benefits, their effect on cruising intention is significantly stronger for younger customers who are inclined to brand as a selfreflection. In contrast, the price has no direct effect on intention to cruise. Therefore, this cruise marketing program does provide some value, but conceivably not in the way the cruise liner company wishes. The cruise industry should anticipate their customers' perpetual characteristics (i.e., their interpretation of luxury vacation and perceived importance of social status reflection through choice of vacation) and review these marketing approaches to ensure that they able to reach out to their customers better rather than just attracting price sensitive customers.
\end{abstract}

\section{Keywords}

Cruise tourism; Malaysian tourist; tourist behaviour; cruise vacation; tourism marketing

\section{Introduction}

The cruise industry in Malaysia is foreseen to grow. Evidently, the increasing number of total cruise passengers in Malaysia from 475,990 passengers in year 2012 to 512,400 as of 2016 indicating a growth of $7.6 \%$ (The Star, 2017). Strategic location, ports infrastructure, rich in cultural and natural attractions are the four main reasons that made Malaysia an interesting cruise destination (Chong, 2014). Other than that, based on ASEAN CRUISE NEWS (2014), the six main ports in Malaysia which comprised of Port Klang, Langkawi, Penang, Melaka, Kota Kinabalu, and Kuching are under progress of being developed and upgraded for the purpose of cruise tourism. In addition, the government is determined to make Malaysia become one of the largest port hubs in Asia. Despite these initiatives and investments, Malaysian market for cruise tourism is still far from sustainable. The breakdown of the cruise tourism is still primarily dominated by the European market (Mondou \& Taunay 2012). Comparatively, the European cruise market has received 6.36 million of passengers in year 2016, Asia cruise market, on the other hand, has only received 2.2 million of passengers in year 2016 (CLIA, 2017). Furthermore, the market within Asia is not evenly distributed with Chinese tourists being the greatest contributors with 83 million of cruise passengers are expected to be brought by China in every year (Travel Cruise News, 2015). The statistics seems to indicate that Asian cruise tourists are still very much dominated by Chinese tourist while other part of Asian market are still relatively small especially from Malaysia. Several academics have called the marketing strategies for cruise liners into question by suggesting that they may be too "European-focused" (Qu \& Ping, 1999; Wang et al., 2014; Sun et al., 2014; Lau et al., 2014) and even going so far as to label them "disconnected" (Soon \& Lam, 2013; Chong, 2014).

Numerous studies have examined on the tourist perception (Shen et al., 2016; Petrick, 2011; Gargano et al., 2012; Duman \& Mattila, 2005; Meng et al., 2011), and motivational factors (Han et al., 2014; Petrick, 2004; Meng et al., 2011; Hung \& Petrick, 2010) in cruising. In spite of this, there are very limited studies concerning the relationship between tourist perceived value and behavioural intention on cruising. The body of knowledge shows that despite of the increasing research topic on cruising, most of the researches conducted were based on European countries (Diedrich, 2010; Brida et al., 2012; Pranić et al., 2013; David, 2014; Brida et al., 2014; Blas 
\& Carvajal-Trujillo, 2014; Carić \& Mackelworth, 2014) whereas there is relatively limited research for Asia (Qu \& Ping, 1999; Wang et al., 2014; Sun et al., 2014; Lau et al., 2014) especially Malaysia (Soon \& Lam, 2013; Chong, 2014). Even though that studies were conducted on examining the relationship between perceived value and behavioural intention (Yi et al., 2014; Chen \& Chen, 2010; Petrick, 2004; Pandža Bajs, 2015; Williams \& Soutar, 2009), however, most of these studies were focused on repurchase intention as well as recommendation intention. The new traveller's purchase intention, however, remained to be inadequate specifically in the study of cruising behaviour.

The critical issue involves how the travellers' perceived value toward cruising projected by current state of promotional approaches interrelates with two fundamental concepts of strategic marketing - purchase intention and market segmentation. Therefore, even as cruise managers often use price promotional tactics to pursue their strategic marketing goals, little is known about the relationship that price promotion has with the success of cruise marketing (Petrick, 2005). This practice of price discounting has formed new challenges for the cruise industry, as they have attracted a more price-sensitive market than before (Petrick, 2005). Due to extensive operation costs, and a segment of business travellers, the cruise industry has had greater struggle integrating price promotional strategy (Petrick, 2005). This emphasis is disputed by academics as efforts to segment travellers have often neglected to make the distinction between customer states and traits but optimistically assume that the cruise market can be categorised in accordance to price-sensitivity (Oh, 2003; Han et al., 2001; Petrick, 2005).

As a result, apart from pricing, little is known about affective factors (e.g emotional attachment, social status, and novelty seeking etc.) in improving travellers cruising intention (Petrick, Li, and Park, 2007; Duman and Mattila, 2005). These non-financial factors can potentially influence the effectiveness of cruise marketing, predominantly in relation to how cruise marketers can use value system to segment cruise travellers (Shen et al., 2016; Ko and Park, 2000). The roles of affective value on travel intentions were further validated in Duman and Mattila's (2005) work suggesting that perceived emotional value, social value and novelty value show significant predicting role on behavioral intentions. Hence, there is a need for cruise management to examine if the price discounts are a feasible marketing strategy and how significant are the affective factors in motivating cruising behaviour among Malaysian. Therefore, the aim of this research is to assess Malaysians' perceived value towards cruising and to explore how perceived emotional value, perceived price attractiveness, perceived social value and perceived novelty can influence their cruising intention (see Figure 1). The outcome of this study will not only enrich the existing literature of cruise tourism especially in the area of customers' motivational factors model but also to facilitate marketing decision in relation to promotional strategies for cruise tourism. 
Figure 1:

\section{Conceptual Model.}

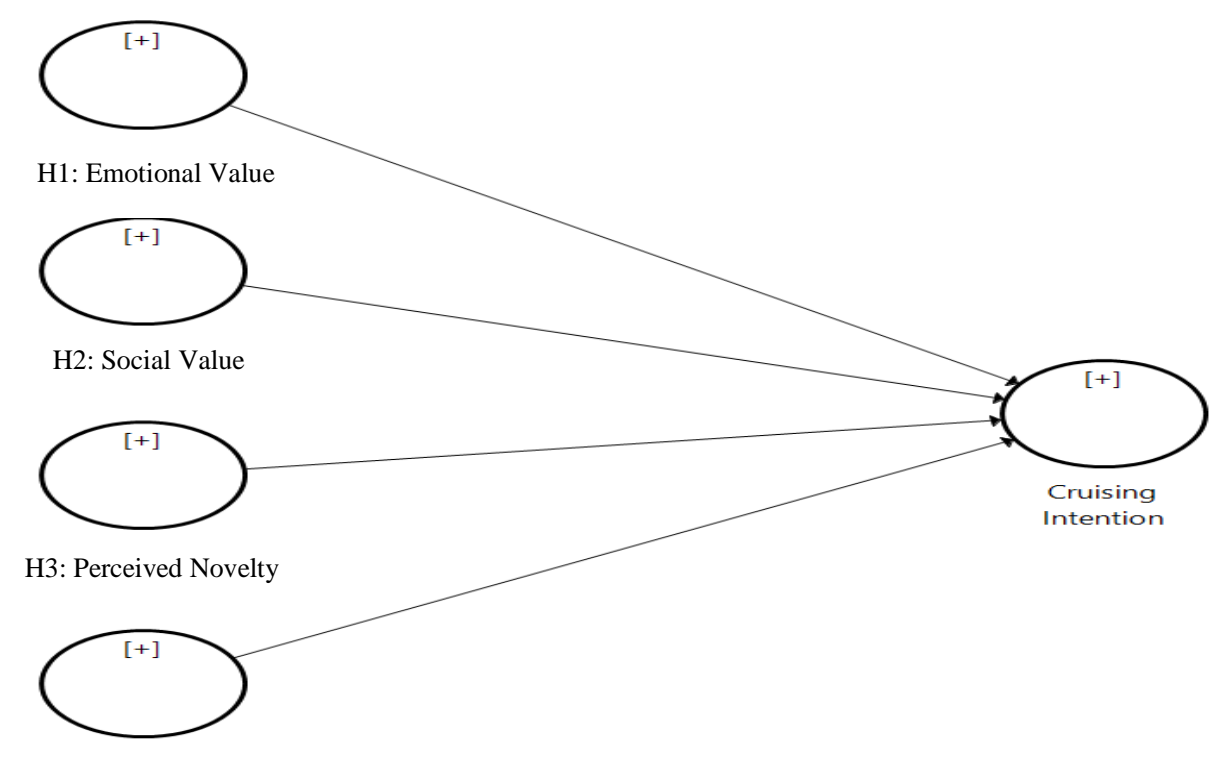

H4: Price Attractiveness

\section{Literature Review}

For any marketing program to be effective in improving traveller's intention, travellers have to value that cruising as ideal vacation alternative (Sheth et al. 1991; Sweeney \& Soutar, 2001; Petrick, 2002; Shen et al., 2016). By this belief, travellers have to perceive value in cruising (Duman \& Mattila, 2005) for them to choose to participate in it. This concept is consistent with Sheth, Newman, and Gross's (1991) theory of consumer choice values suggesting that consumer choice behaviour is directed by multiple consumption values. Their study suggested five consumption values that governing consumers' decision making (functional value, social value, emotional value, epistemic value, and conditional value). These multiple values in turn self-sufficiently and differentially effect a consumer's choice of consumption. This concept applies to all sort of travellers and is therefore appropriate in the context of cruising.

This framework of five consumer values aligns closely with the offerings provided through most cruise marketing programs, as follows. Functional value can be assumed as the perceived usefulness acquired from the performance of the cruising services, such that a traveller may perceive higher value if the cruising services are reliable and high in quality. However, this assumption was excluded in this study noting that perceived functionality of a services cannot be easily measured or formed in the mind of a consumers due to the nature of intangibility in services (Pleger Bebko, 2000). Furthermore, it may not be feasible for marketers to project or demonstrate functionality of cruising services in the form of any marketing activities unless it was carried out in the form of experiential approach. Even with that in mind, sampling services to project its functionality may not be feasibly carried out (Cronin et al., 2000). Hence, this study only focus on what marketers can realistically working on: (1) The social value, (2) the emotional value, (3) epistemic value (perceived novelty), and (4) conditional value (price attractiveness).

Social value is defined as 'the utility derived from the product's ability to enhance social self-concept' (Sweeney \& Soutar 2001, p. 211). In other words, consumer purchase specific products to serve as symbolic markers of group membership (Vigneron \& Johnson, 2004). In this study, the social value is interpreted as the 
perceived utility acquired from the cruising activities association with one or more specific social groups, such that a consumer may perceive higher value if the cruising is associated with a desirable social group (e.g. high earning group). This argument was well-supported by Bearden et al' (1989) study indicating that social environment and interpersonal interactions can both strongly influence consumer behaviour. In other words, consumer buying behaviour can be influenced by what others might think of them in relation to their product choice. Thus, boarding onto a luxury cruise liner aims to improve one's rank in society. This effect is particularly noteworthy in Malaysia where collectivistic cultures highlight the likelihood of a person to comply with the ingroup's norms in view of purchasing decision (Ghazali et al., 2017). In such market, western way of traveling establishes one's social identity and impart prestige to consumers by symbolising affluent western lifestyles (Alden et al. 1999). In Malaysia, a significant motive for trying foreign products or services is to attain social standing (Mamat et al., 2016). Their studies indicated that Malaysian tends to emphasize on the social meaning of a product, which establishes their social position and earns admiration from others. Hence, it can be assumed that if the symbolic value of cruising increases, travellers' inclination to cruise will also increases. Therefore, perceived social value should be an important motivation driving cruising intention in Malaysia.

Hypothesis 1 (H1): Perceived social value has a significant influence on cruising intention.

Perceived emotional value is the awareness of 'the utility derived from the feelings or affective states that a product generates' (Sweeney \& Soutar 2001, p. 211). Their study suggested that consumers desire emotional benefit through ownership of certain products and services (Sheth et al. 1991; Hagtvedt \& Patrick 2009). In view of cruising, travellers' emotional value refers to the cruise marketing ability to create affective states, such that a traveller may perceive higher value if the cruise marketing program creates positive emotions. In the past, Malaysian consumers place great importance on the functionality of a product or service but they have changed to value enjoyment in partaking a product or service due to the impact of global hospitality standards. Many multinational hospitality establishments have introduced more materialistic approach in achieving better emotional attachment among Malaysian consumers (Ali et al., 2016). Today's Malaysian consumers have accepted buying for enjoyment reason rather than just functional reasons. Ali et al. (2016) discovered that Malaysian consumers with high hedonic desire are expected to obtain international brand name hospitality products and services. Cruising is linked with hedonic pleasure through features like aesthetic interior designs, sophisticated facilities, 5 star services and exciting food range and leisure activities (Jani \& Han, 2015). Hence, this study hypothesize that Malaysian tend to satisfy their emotional needs through cruising.

Hypothesis 2 (H2): Perceived emotional value has a significant influence on cruising intention.

The perceived novelty refers to the perceived utility acquired from the cruising's ability to pique curiosity, or satisfy a desire for knowledge, such that a traveller may perceive higher value if the cruising provides new experiences. Novelty value is also interrelated to the perceived exclusivity of a product or services. Consumers tend to distinguish themselves from others (Snyder \& Fromkin 1977). Synder and Fromkin (1977) argued that the desire of exclusivity is derived from a social comparison process, which is an indispensable constituent of the development of the personality. When a person perceives themselves as too alike to others, they may feel that their individuality is susceptible and hence need to act in conducts that make them feel ahead of others or at least different. Because trying new services or products can represent the extended self (Roehrich, 2004). Consumers looking for novelty tend to avoid acquiring products or services preferred by the mainstream. Cruise liners are infrequent because of their high price and restricted destinations and inflexible schedule (Chong, 2014; Véronneau \& Roy, 2009). In this case, cruising can be seen as an ideal travelling choice to establish one's uniqueness to others. Therefore, perceived novelty should positively relate to travellers' cruising decision. 
Hypothesis 3 (H3): Perceived novelty positively influences cruising intention.

Finally, the conditional value is the perceived utility acquired from the cruising as a result of an immediate benefits, such as discounts on normal prices. Pricing strategy is one of the most desire technique in drawing more sales (Han, Gupta, \& Lehman, 2001). Sales promotion or reduction in normal price can significantly influences tourists' decision-making processes, and is vastly related to intentional behaviour (Stienmetz \& Fesenmaier, 2013; Kalyanaram \& Winer, 1995). From the aspect of tourism, price is applied inversely by the several hospitality segments. The airline industry has been the most innovative (Orkin, 1990), by successfully using yield management. These approaches have subsequently been introduced into the cruise industry. Price discounts improve perceived value and increase purchase intention (Grewal, Monroe \& Krishnan, 1998). Additional, price reduction impacts consumers' price perceptions and product evaluations (Alba, Mela, Shimp, \& Urbany, 1999). Both discount size and number of deals may boost the perceived attractiveness of the promotional offer. This research proposes that in the context of cruising, new travellers are more likely to try cruising given that discounted price could help to reduce perceived financial risk. Hence, this study hypothesize that the perceived price attractiveness will affect the cruising intention of a new travellers.

Hypothesis 4 (H4): Price Attractiveness positively influences cruising intention.

\section{Method and Results}

The objective of the study is to measure the perceived value of Malaysians towards cruising and how various perceived value can affect their cruising intention. In view of predictive approach in the study, research stimuli are needed to assist respondent to answer the survey effectively and more realistically. A sample of cruise promotional leaflet was carefully selected based on 3 important criteria: 1) Content which reflect pricing, 2) graphic and pictures which promote emotional and social engagement and 3) claims that promote exploration, new destinations and new features of the cruise liner. This study was conducted in Selangor as it is the most developed and populated region amongst the other states in Malaysia. According to the Department of Statistics Malaysia (2016), Selangor has the highest population with 5.46 million of population as of 2016. In addition, the largest port in Malaysia is in the state of Selangor (World Port Source, 2015). Therefore, the population frame of respondents in Selangor are more likely to have higher degree of awareness on the presence of cruising. Snowball sampling technique was used in gathering relevant respondents. 2 screening questions were administered in recognizing potential respondents: 1) intention to travel in coming months and 2) show certain degree of involvement in vacation planning and decision making. During the data collection stage, respondents were approached with 2 screening questions pertaining to their interest and degree of involvement in cruising decision. Once the eligibility of the respondents was established, they were briefed about the purpose of the survey and consent of the participation were also obtained before attending to the survey. The survey was broken down into 2 stages: at the first part of the survey, respondents were prompted with statements pertaining to their agreement towards a list of information stated in the cruise tour promotional leaflet predetermined in accordance to the 4 controlled variables (Emotional Value, Social Value, Perceived Novelty and Price Attractiveness); the final part of the survey requested respondents to state their intention to purchase the cruise tour package prepared as the stimuli in the experiment. The study receives a total of 159 responses, we then retained 133 responses after data cleaning by eliminating missing value and any possible straight-line error found in the data.

The sample was evenly divided between men and women, and the average age was 30 years. The respondents were preponderantly Malaysian Chinese (52.6\%), with small percentages of Malay (25.4\%), Indian (18\%) and others mainly the minorities of Malaysian natives. The sample was generally well educated, as 81 percent had finished at least their undergrads and the median household income range was RM80,000 to RM100,000. 
Figure 2:

\section{Scale Statistics and}

Correlations.

\section{Correlations}

\begin{tabular}{lccccccccc} 
Variables & $M$ & $S D$ & CR & AVE & 1 & 2 & 3 & 4 & 5 \\
& & & & & & & & & \\
1.Cruising Intention & 4.82 & 1.23 & 0.84 & 0.65 & .80 & & & \\
2.Perceived Emotional Value & 5.19 & 1.01 & 0.92 & 0.94 & $.68^{*}$ & .87 & & & \\
3.Perceived Novelty & 4.84 & -0.12 & 0.88 & 0.66 & $.56^{*}$ & $.51^{*}$ & .81 & & \\
4.Perceived Social Value & 3.40 & -0.29 & 0.92 & 0.88 & $.41^{*}$ & $.29^{*}$ & $.40^{*}$ & .81 & \\
5.Perceived Price Attractiveness & 4.12 & -0.46 & 0.89 & 0.73 & $.37^{*}$ & $.53^{*}$ & $.40^{*}$ & $.33^{*}$ & .85 \\
\hline
\end{tabular}

Note. The square root of the AVEs are provided on the diagonal in bold italics. $\mathrm{CR}=$ construct reliability; AVE = average variance extracted. ${ }^{*} p<.05$.

\section{Measurement}

Adapted multiple item-scales were used to measure all the variables. All variables were measured using 5point Likert-type scales (as shown in the appendix). The survey instruments for perceived value comprised of items measuring perceived emotional value, perceived price attractiveness, perceived social value and perceived novelty with five items in perceived emotional value and four items each in perceived price, perceived social value and perceived novelty. As for cruising intention, it consist of three items which evaluates the selfintention and the recommendation of cruising to others. The measurement scale for perceived value are derived from Sweeney and Soutar (2001)'s model while behavioral intention from Parasuraman et al. (1988). All of the items for this section are measured in a seven-point Likert scale ranging from 1 which is strongly disagree to 7 strongly agree. Based on Sweeney and Soutar's (2001) conceptualization, we define perceived value of the cruising program as an valuation of the overall utility of cruising based on their perceptions of emotional attachment, social representation, service novelty and financial benefits.

\section{Measurement Testing}

The formulated measurement model containing all variables was assessed, where all items were forced to load on their respective factors. The measurement model fit the data well, $\chi^{2}(d f=133)=380.68$, Normed Fit Index $(\mathrm{NFI})=0.78$, standardized root mean square residual $(\mathrm{SRMR})=0.09$. Convergent validity was established, with $t$ values revealed that all items loaded highly and significantly on their proposed variable and the average variance extracted for each multi-item construct exceeded 0.50 (Fornell and Larcker 1981). The square root of the average variance extracted for each construct also exceed the correlation with all other constructs, providing indication of discriminant validity (Fornell and Larcker 1981). Finally, construct reliabilities for all scales exceed 0.80. Scale statistics are provided in Figure 2.

\section{Hypothesis Testing}

After the measurement assessment, a structural equation model was projected to test $\mathrm{H} 1, \mathrm{H} 2, \mathrm{H} 3$, and $\mathrm{H} 4$, all of most were supported by the data except H4 (see Figure 3). To estimate the structural equation model with an endogenous interaction, the study followed the recommendations of Ping (2009), and correlations between the cruising intention and the perceived value of the cruising program construct were specified. Perceived social value $(\beta=.18)$, Perceived emotional value $(\beta=.54)$ and Perceived Novelty $(\beta=.25)$, significantly affected 
cruising intention $(p<.05)$, hence, $\mathrm{H} 1$. $\mathrm{H} 2$ and $\mathrm{H} 3$ were supported. However, the analysis rejected $\mathrm{H} 4$ showing insignificant relationship between H4: Perceived Price Attractiveness $(\beta=-0.07, p>.05)$ and Cruising Intention. In all, after the exclusion of Price Attractiveness as one of the predictors, the model explained control and predictor variables explained 55 percent of the variance in cruising intention.

Figure 3:

\begin{tabular}{llccccccc}
\hline Results of Hypothesis Testing (H1 to H4). & & & & & & & & \\
\hline & & Std & Std & & & & & \\
& Hypothesis Path & Beta & Error & t-value & P Values & f2 & VIF & R2 \\
H1 & Perceived Social Value -> Cruising Intention & 0.18 & 0.08 & 2.34 & 0.02 & 0.06 & 1.249 & 0.55 \\
H2 & Perceived Emotional Value -> Cruising Intention & 0.54 & 0.07 & 7.27 & 0.00 & 0.40 & 1.64 \\
H3 & Perceived Novelty -> Cruising Intention & 0.25 & 0.07 & 3.31 & 0.00 & 0.09 & 1.52 \\
H4 & Price Attractiveness -> Cruising Intention & -0.07 & 0.08 & 0.92 & 0.36 & 0.01 & 1.487 \\
\hline
\end{tabular}

\section{Conclusion}

The results of this study offer a more comprehensive understanding of the relationship between consumers' perceived value and behavioural intention in cruising. For this cruising program, this study validates that its perceived value pertaining to emotional engagement, social uplifting and perceived novelty enhances traveller's intention to cruise but disapprove the impact of price promotion. This discovery provides suggestion that marketing cruising as luxury, enjoyable and explorative vacation can improve the success a cruise firm rather than overly focus on price promotional. Thus, this study concludes that the marketing plan for Asia's cruise liner that heavily focus on price promotion are basically ineffective at driving new travellers. This finding concur with several past studies that marginal changes in price may not be effective in enticing customers' purchase intention (Gupta \& Cooper, 1992; Kalwani \& Yim, 1992). Thus, consumers who experience price differentials within this tolerance zone (zone of price insensitivity), do not experience any positive or negative gain from such price promotional activities. 


\section{Theoretical Implications}

This study can be considered the first that integrate perceived emotional, social, novelty and price attractiveness with first purchase intention in the context of cruising. Although Hung and Petrick (2010) outlined the possible motivational factors that could affect cruising behaviour, there have been few if any direct tests of the effects of cruising value on behavioural consequences. Having studied the matter of perceived value, this study proves the need for research not only on the impact of perceived value on cruising behaviour but also on consumer attitudes towards cruising marketing program. Future studies can add on to this foundation to empirically recognize how cruise liners' marketing managers can improve travellers' perceptions of the emotional value, social value and perceived novelty towards a cruise vacation program and the influence of such strategies on a wider collection of attitudinal assessments of the cruise company.

Generally, this study addresses directly to the call by Hung and Petrick (2010) for more research on cruising behaviour, a topic they have studied in considerable depth. In the past, many researches on cruising behaviour has examined models that link the customer experience, particularly service quality, on re-purchase intentions (notably, Li and Petrick, 2008). This study extends results from these initial models by signifying the corresponding function of the affective value of a cruise program in predicting customers' cruising intentions after considering the fundamental effects of service quality.

\section{Managerial Implications}

Conceivably the utmost significant contribution of this study is the importance of linking the cruise marketing program with the market recognition and positioning of cruise vacation. Managers should appropriately measure the brand identity of cruising in the mind of the targeted travellers, given that customers' perceptions of cruising can directly effects on their intention to cruise. Due to the importance of cruising as the symbolic meaning of social status, emotional fulfilment and exploration, cruise liner managers should uphold an importance on cultivating brand perceptions and ensuring that the cruise marketing program offers emotional, social and novelty value. This study suggests that the provision of a highly-valued cruise program can increase cruising intention. For effective cruise branding, their image projections not only influence consumer cruising intention, but can also strengthen consumer attitudes toward the cruise liner. As such, this study recommends two tactics. Cruise liners required to concentrate on differentiating their marketing programs from their competitors and similarly on increasing the perceived emotional, social and novelty value through their promotional efforts. One way to elevate cruising experience and evaluation is to position their cruising program as being a privilege. Managers must also try to offer emotionally and socially meaningful rewards to their onboard travellers. These modest modifications can result in increases in both consumer intention, further spending and referral behavior (Kivetz and Simonson 2003).

Irrespective of a cruise liner's marketing strategies, their impact on traveller's intention will differ conferring to the consumers' characteristics (Meyer-Waarden 2008). In actual, affective-based promotional activities are conspicuously ineffective at persuading travellers who are susceptible to be price sensitive and utility value driven. However, enhancements in the perceived affective value of a cruise program will entice the first-timers, resulting directly in increases in new users, who are wanted to try new travelling experience. Therefore, when improved cruise marketing programs seem to be attracting more new travellers, a cruise firm is unlikely to convert these new users into loyalists unless the cruise firm can strategize continued value. That appears doubtful given the intense competition among many cruise companies in the market. Though that this condition seems discouraging, our discoveries accentuate the standing of better consumer research to confirm that customers' affective rewards are to be considered equally important than functional and financial benefits in the context of cruising. 
The call for marketing segmentation contends for a need for better differentiation of cruise programs to ensure that all customers recognize the financial and non-financial value offered by a cruise liner. Marketing essentials that might realize this comprise differential offerings for Asian and non-Asian travellers, unique intangible features, and engagement opportunities. In short, cruise managers are required to structure their marketing plan to better segment their customer bases and to differentiate their cruise programs from their competition. In conclusion, as this study inspected a cruise liner promotional plan, future study is needed to determine whether the findings of this study can be generalized in other similar markets measured by cultural proximity and market maturity.

\section{Limitations}

The limitation of this study mainly pertaining to the scope of the research areas. The experiment is restricted to the concentration on Malaysian cruising behaviour as a whole and did not discriminate the variance between demographic, social cultural and customer knowledge differences. Nevertheless, this research able to offer substantial intuitions of the cruising behaviour among Malaysian tourists. Upcoming research is recommended to examine the possible moderating effects of demographic, social cultural and customers' knowledge differences towards the theoretical relationships suggested in this study. 


\section{Appendix}

\section{Measurement Items}

All items are scored using a 7-point Likert-type scale, where $0=$ Strongly Disagree and $7=$ Strongly Agree unless other-wise noted.

Perceived Emotional Value

This cruise liner is one that I would enjoy.

This cruise liner would make me want to experience it.

This cruise liner is one that I would feel relaxed.

This cruise liner would make me feel good.

This cruise liner would give me pleasure.

Perceived Social Value

This cruise liner would help me to feel up to standard.

This cruise liner would improve the way how people see me.

This cruise liner would make a good impression on other people.

This cruise liner would make me easy to be accepted by other people.

Perceived Novelty

This cruising program is adventurous

This cruising program helps to explore new things

This cruising program provides me new experience

This cruising program helps me to see something that I have never seen before

Price Attractiveness

This cruising program is reasonably priced.

This cruising program offers value for money.

This cruising program is a good product for the price.

This cruising program would be economical.

Cruising Intention

I would be willing to travel by this cruise.

I would recommend this cruise program to friends or relatives.

I would love to try this cruise program. 


\section{Declaration of Conflicting Interests}

The author(s) declared no potential conflicts of interest with respect to the research, authorship, or publication of this article.

\section{Funding}

The author(s) received no financial support for the research, authorship, or publication of this article.

\section{References}

Ali, F., Hussain, K., \& Omar, R. (2016). Diagnosing customers experience, emotions and satisfaction in Malaysian resort hotels. European Journal of Tourism Research, 12, 25.

Alba, J. W., Mela, C. F., Shimp, T. A., \& Urbany, J. E. (1999). The effect of discount frequency and depth on consumer price judgments. Journal of Consumer Research, 26(2), 99-114.

Alden, D. L., Steenkamp, J. B. E., \& Batra, R. (1999). Brand positioning through advertising in Asia, North America, and Europe: The role of global consumer culture. The Journal of Marketing, 75-87.

ASEAN CRUISE NEWS (2014, October 12). Malaysia develops cruise industry. ASEAN CRUISE NEWS. Retrieved from http://www.aseancruising.com/malaysia-develops-cruise-industry/

Brida, J. G., Pulina, M., Riaño, E., \& Zapata-Aguirre, S. (2012). Cruise passengers' experience embarking in a Caribbean home port. The case study of Cartagena de Indias. Ocean \& Coastal Management, 55, 135-145.

Bearden, W. O., Netemeyer, R. G., \& Teel, J. E. (1989). Measurement of consumer susceptibility to interpersonal influence. Journal of consumer research, 15(4), 473-481.

Brida, J. G., Fasone, V., Scuderi, R., \& Zapata-Aguirre, S. (2014). Research note: Exploring the determinants of cruise passengers' expenditure at ports of call in Uruguay. Tourism Economics, 20(5), 1133-1143.

Blas, S. S., \& Carvajal-Trujillo, E. (2014). Cruise passengers' experiences in a Mediterranean port of call. The case study of Valencia. Ocean \& coastal management, 102, 307-316.

Chong, K. L. (2014). Cruise tourism in Malaysia: A SWOT analysis. Theory and Practice in Hospitality and Tourism Research, 189.

Lee, T. H., \& Crompton, J. (1992). Measuring novelty seeking in tourism. Annals of tourism research, 19(4), 732-751.

Carić, H., \& Mackelworth, P. (2014). Cruise tourism environmental impacts-The perspective from the Adriatic Sea. Ocean \& coastal management, 102, 350-363.

Cronin, J. J., Brady, M. K., \& Hult, G. T. M. (2000). Assessing the effects of quality, value, and customer satisfaction on consumer behavioral intentions in service environments. Journal of retailing, 76(2), 193-218.

Chen, C. F., \& Chen, F. S. (2010). Experience quality, perceived value, satisfaction and behavioral intentions for heritage tourists. Tourism management, 31(1), 29-35.

Cronin, J. J., Brady, M. K., \& Hult, G. T. M. (2000). Assessing the effects of quality, value, and customer satisfaction on consumer behavioral intentions in service environments. Journal of retailing, 76(2), 193-218.

CLIA (2017, May). Global Passengers Number for 2016. Retrieved from: https://www.cruising.org/about-the-industry/press-room/press-releases/pr/cruise-lines-internationalassociation-releases-official-global-passenger-numbers-for-2016

David Mc A, B. (2015). Exploring Cruise Passengers' Demographics, Experience, and Satisfaction with Cruising the Western Caribbean. International Journal of Tourism \& Hospitality Reviews, 1(1), 2331.

Duman, T., \& Mattila, A. S. (2005). The role of affective factors on perceived cruise vacation value. Tourism Management, 26(3), 311-323.

Diedrich, A. (2010). Cruise ship tourism in Belize: The implications of developing cruise ship tourism in an ecotourism destination. Ocean \& Coastal Management, 53(5), 234-244.

Department of Statistics Malaysia (2016). Population distribution and basic demographic characteristic report 2016-17. Retrieved from https://www.dosm.gov.my/v1/index.php?r=column/cthemeByCat\&cat=155\&bul_id=a1d1UTFZazd5a jJiRWFHNDduOXFFQT09\&menu_id=L0pheU43NWJwRWVSZkIWdzQ4TlhUUT09

Fornell, C., and D. F. Larcker (1981). Evaluating structural equa-tion models with unobservable variables and measurement error. Journal of Marketing Research 18 (1): 39-50. 
Gupta, S., \& Cooper, L. G. (1992). The discounting of discounts and promotion thresholds. Journal of consumer research, 19(3), 401-411.

Grewal, D., Monroe, K. B., \& Krishnan, R. (1998). The effects of price-comparison advertising on buyers' perceptions of acquisition value, transaction value, and behavioral intentions. The Journal of Marketing, 46-59.

Ghazali, I., Abdul-Rashid, S. H., Dawal, S. Z. M., Aoyama, H., Tontowi, A. E., \& Sakundarini, N. (2017). Cultural influences on choosing green products: An empirical study in Malaysia. Sustainable Development.

Gargano, R., Avena, G., \& Mondello, M. (2012). Cruise tourism in Messina: A study on the perception of services. Rivista Italiana di Economia Demografia e Statistica, 66(3/4), 119-126.

Hung, K., \& Petrick, J. F. (2011). Why do you cruise? Exploring the motivations for taking cruise holidays, and the construction of a cruising motivation scale. Tourism Management, 32(2), 386-393.

Hagtvedt, H., \& Patrick, V. M. (2009). The broad embrace of luxury: Hedonic potential as a driver of brand extendibility.

Han, S., Gupta, S., \& Lehmann, D. R. (2001). Consumer price sensitivity and price thresholds14. Journal of retailing, 77(4), 435-456.

Jani, D., \& Han, H. (2015). Influence of environmental stimuli on hotel customer emotional loyalty response: Testing the moderating effect of the big five personality factors. International Journal of Hospitality Management, 44, 48-57.

Kalyanaram, G., \& Winer, R. S. (1995). Empirical generalizations from reference price research. Marketing science, 14(3_supplement), G161-G169.

Kalwani, M. U., \& Yim, C. K. (1992). Consumer price and promotion expectations: An experimental study. Journal of marketing Research, 90-100.

Kivetz, R., \& Simonson, I. (2003). The idiosyncratic fit heuristic: Effort advantage as a determinant of consumer response to loyalty programs. Journal of Marketing Research, 40(4), 454-467.

Ko, D. W., \& Park, S. H. (2000). Five aspects of tourism image: A review. International Journal of Tourism Sciences, 1(1), 79-92.

Lau, Y. Y., Tam, K. C., Ng, A. K., \& Pallis, A. A. (2014). Cruise terminals site selection process: An institutional analysis of the Kai Tak Cruise Terminal in Hong Kong. Research in Transportation Business \& Management, 13, 16-23.

Li, X., \& Petrick, J. F. (2008). Reexamining the dimensionality of brand loyalty: A case of the cruise industry. Journal of Travel \& Tourism Marketing, 25(1), 68-85.

Mamat, M. N., Noor, N. M., \& Noor, N. M. (2016). Purchase intentions of foreign luxury brand handbags among consumers in Kuala Lumpur, Malaysia. Procedia Economics and Finance, 35, 206-215.

Meyer-Waarden, L. (2008). The influence of loyalty programme membership on customer purchase behaviour. European Journal of marketing, 42(1/2), 87-114.

Meng, S. M., Liang, G. S., \& Yang, S. H. (2011). The relationships of cruise image, perceived value, satisfaction, and post-purchase behavioral intention on Taiwanese tourists. African Journal of Business Management, 5(1), 19.

Mondou, V., \& Taunay, B. (2011). The adaptation strategies of the cruise lines to the Chinese tourists. Turizam: međunarodni znanstveno-stručni časopis, 60(1), 43-54.

Oh, H. (2003). Price fairness and its asymmetric effects on overall price, quality, and value judgments: the case of an upscale hotel. Tourism Management, 24(4), 387-399.

Orkin, E. B. (1990). Strategies for managing transient rates. The Cornell Hotel and Restaurant Administration Quarterly, 30(4), 34-39.

Pranić, L., Marušić, Z., \& Sever, I. (2013). Cruise passengers' experiences in coastal destinationsFloating "B\&Bs" vs. floating "resorts": A case of Croatia. Ocean \& coastal management, 84, 1-12.

Parasuraman, A., V. A. Zeithaml, and L. L. Berry. 1988. SERVQUAL: A multiple-item scale for measuring con-sumer perceptions of service quality. Journal of Retailing 64 (Spring): 12-40.

Pandža Bajs, I. (2015). Tourist perceived value, relationship to satisfaction, and behavioral intentions: The example of the Croatian tourist destination Dubrovnik. Journal of Travel Research, 54(1), 122134.

Petrick, J. F. (2002). Development of a multi-dimensional scale for measuring the perceived value of a service. Journal of leisure research, 34(2), 119.

Petrick, J. F. (2004). The roles of quality, value, and satisfaction in predicting cruise passengers' behavioral intentions. Journal of travel research, 42(4), 397-407.

Petrick, J. F., Li, X., \& Park, S. Y. (2007). Cruise passengers' decision-making processes. Journal of Travel \& Tourism Marketing, 23(1), 1-14.

Petrick, J. F. (2005). Segmenting cruise passengers with price sensitivity. Tourism Management, 26(5), 753-762. 
Petrick, J. F. (2011). Segmenting cruise passengers with perceived reputation. Journal of Hospitality and Tourism Management, 18(1), 48-53.

Pleger Bebko, C. (2000). Service intangibility and its impact on consumer expectations of service quality. Journal of Services Marketing, 14(1), 9-26.

Qu, H., \& Ping, E. W. Y. (1999). A service performance model of Hong Kong cruise travelers' motivation factors and satisfaction. Tourism management, 20(2), 237-244.

Roehrich, G. (2004). Consumer innovativeness: Concepts and measurements. Journal of business research, 57(6), 671-677.

Roehrich, G. (2004). Consumer innovativeness: Concepts and measurements. Journal of business research, 57(6), 671-677.

Stienmetz, J. L., \& Fesenmaier, D. R. (2013). Traveling the network: A proposal for destination performance metrics. International Journal of Tourism Sciences, 13(2), 57-75.

Hyun, S. S., \& Han, H. (2015). Luxury cruise travelers: Other customer perceptions. Journal of Travel Research, 54(1), 107-121.

Shen, H., Fan, S., Zhan, J., \& Zhao, J. (2016). A Study of the Perceived Value and Behavioral Intentions of Chinese Marine Cruise Tourists. Tourism, Leisure and Global Change, 1(1), CUHK-96.

Sheth, J. N., Newman, B. I., \& Gross, B. L. (1991). Why we buy what we buy: A theory of consumption values. Journal of business research, 22(2), 159-170.

Sweeney, J. C., \& Soutar, G. N. (2001). Consumer perceived value: The development of a multiple item scale. Journal of retailing, 77(2), 203-220.

Sun, X., Feng, X., \& Gauri, D. K. (2014). The cruise industry in China: Efforts, progress and challenges. International Journal of Hospitality Management, 42, 71-84.

Soon, C., \& Lam, W. H. (2013). The growth of seaports in Peninsular Malaysia and East Malaysia for 2007-2011. Ocean \& coastal management, 78, 70-76.

Snyder, C. R., \& Fromkin, H. L. (1977). Abnormality as a positive characteristic: The development and validation of a scale measuring need for uniqueness. Journal of Abnormal Psychology, 86(5), 518.

Travel Cruise News (2015, October 10). China plots domination of the global cruise market. Travel Cruise News. Retrieved from http://www.telegraph.co.uk/travel/cruises/cruise-news/11455210/China-plotsdomination-of-the-global-cruise-market.html

The Star (2017, August 2). New attractions and deals for cruise vacations. The Star News. Retrieved from: http://www.thestar.com.my/metro/community/2017/08/02/new-attractions-and-deals-for-cruisevacations-various-promotions-offered-at-oneday-event/

Véronneau, S., \& Roy, J. (2009). Global service supply chains: An empirical study of current practices and challenges of a cruise line corporation. Tourism Management, 30(1), 128-139.

Vigneron, F., \& Johnson, L. W. (2004). Measuring perceptions of brand luxury. The Journal of Brand Management, 11(6), 484-506.

Williams, P., \& Soutar, G. N. (2009). Value, satisfaction and behavioral intentions in an adventure tourism context. Annals of Tourism Research, 36(3), 413-438.

Wang, Y., Jung, K. A., Yeo, G. T., \& Chou, C. C. (2014). Selecting a cruise port of call location using the fuzzy-AHP method: A case study in East Asia. Tourism Management, 42, 262-270.

World Port Source (2015). Port Klang. Retrieved from http://www.worldportsource.com/ports/review/MYS_Port_Klang_273.php

Yi, S., Day, J., \& Cai, L. A. (2014). Exploring tourist perceived value: An investigation of Asian cruise tourists' travel experience. Journal of quality assurance in hospitality \& tourism, 15(1), 63-77. 